\title{
PELESTARIAN BANJAR SEBAGAI PECEGAHAN TINDAKAN KORUPSI
}

\author{
Novitasari \\ Fakultas Ilmu Sosial dan Politik, Universitas Tidar \\ bbqenak@untidar.ac.id \\ Ahmad Busrotun Nufus \\ Fakultas Ilmu Sosial dan Politik, Universitas Tidar \\ busro@untidar.ac.id
}

\begin{abstract}
Abstrak
Tindakan pemberantasan korupsi di Indonesia telah gencar dilakukan oleh lembaga yang berwenang. Sedangkan tindakan pencegahan yang ditujukan pada lingkungan masyarakat hingga komunitas terkecil yaitu keluarga belum terlalu difokuskan. Oleh karena itu, tujuan penelitian ini adalah untuk mengungkap bagaimana banjar dapat dilestarikan sehingga mendukung pencegahan terjadinya korupsi. Penelitian ini menggunakan pendekatan kualitatif dengan metode studi kasus. Teknik pengumpulan data menggunakan wawancara dan studi litelatur. Teknik analisis data menggunakan model Miles and Huberman. Hasil penelitian menunjukekan babwa pelestarian banjar di lingkungan keluarga dan masyarakat menggunakan pendekatan habituasi dan keteladanan. Saran-saran yang dapat penulis berikan berdasarkan hasil penelitian ini, yaitu: 1) Banjar sebagai upaya pembangunan budaya anti korupsi penting dilestarikan dengan melibatkan keluarga, masyarakat, dan sekolab; 2) Kurikulum pendidikan di sekolah dasar hingga pendidikan tinggi dapat disisipkan materi tentang nilai-nilai anti korupsi dalam tradisi banjar sehingga dapat dilakukan penilaian secara terstuktur.
\end{abstract}

Kata Kunci: Banjar, Nilai Anti Korupsi, Lombok, Tradisi, Kearifan Lokal

\begin{abstract}
The purpose of this study is to reveal how banjar can support the prevention of corruption. This study uses a qualitative approach with a case study method. The results showed that the preservation of banjar in the family and community environment used the habituation and exemplary approach. There are two suggestions based on this study, namely: 1) Banjar as an effort to develop an anti-corruption culture is important to be preserved by involving families, communities, and schools; 2) The curriculum in schools can be inserted anticorruption values in the banjar tradition so that a structured assessment can be carried out.
\end{abstract}

Keywords: Banjar, Lombok, Anti-Corruption, Culture, Local Wisdom

\section{PENDAHULUAN}

Korupsi menjadi permasalahan yang sangat sulit untuk diberantas secara total, bukan hanya bangsa Indonesia saja yang mengalami permasalahan tersebut, akan tetapi berbagai negara maju seperti China, dan Rusia juga memiliki permasalahan yang sama. Transparency International menjelaskan bahwa korupsi merupakan sikap atau tindakan yang secara tidak wajar dan tidak legal guna memperkaya diri sendiri atau memperkaya mereka yang dekat dengannya, dengan cara menyalahgunakan kekuasaan publik atau jabatan yang dipercayakan kepada mereka. Sedangkan dalam Undang-Undang
No. 26 Tahun 1999 tentang penyelenggaraan negara yang bersih dan bebas dari korupsi pada pasal 1 butir 3 disebutkan bahwa korupsi adalah hal ikhwal atau keadaan yang menyertai perbuatan, keadaan tambahan yang memberatkan pidana, dan unsur melawan hukum. Sehingga bisa diambil kesimpulan bahwa tindakan korupsi yang dilakukan oleh koruptor di Indonesia merupakan tindakan yang melawan hukum dan tergolong tindak pidana.

Indonesia selalu disuguhi oleh berbagai permasalahan yang berkaitan dengan tindak pidana korupsi. Berdasarkan olah data yang dilakukan oleh 
Indonesia Corruption Watch (ICW) disebutkan bahwa pada Semester I tahun 2018 kerugian yang dialami oleh negara akibat dari tindakan Korupsi sebesar Rp.1,09 Triliun dan nilai suap Rp 42, 1 Miliar. Dengan kasus Korupsi sebanyak 139 Kasus dan tersangka 351 Orang baik dari Kalangan Aparatur Sipil Negara (ASN), Anggota DPRD, Swasta, Kepala Desa, Kepala Daerah, Pejabat Pengadaan ataupun Masyarakat.

Transparansi Internasional Indonesia (TII) menyebutkan bahwa Indonesia mengalami kenaikan pada Skor Corruption Perception Index (CPI) menjadi 38 sehingga menempatkan Indonesia pada peringkat 89 dari 180 negara korup di dunia. Indonesia mengalami peningkatan dari pada sebelumnya, yang mana menurut Transparency International merilis Indeks Persepsi Korupsi (IPK) 2017 menunjukkan bahwa Indonesia menduduki peringkat ke-96 dari 180 negara di dunia yang paling bersih dari korupsi. Meskipun mengalami kenaikan namun tingkat permasalahan korupsi di Indonesia masih cukup memprihatinkan dan secepatnya harus diselesaikan.

Berbagai Permasalahan korupsi yang ada di Indonesia tentu harus segera diselesaikan baik itu yang sifatnya pencegahan (Preventive) ataupun penindakan (Curative). Bukan hanya tanggung jawab Pemerintah Indonesia saja, atau KPK saja, melainkan juga menjadi tanggung jawab masyarakat. Salah satu bentuk kegiatan yang mampu mencegah tindakan korupsi dan menumbuhkan sikap anti korupsi adalah melalui kearifan lokal yang dimiliki suku Sasak yang berada di Lombok Nusa Tenggara Barat yaitu tradisi "Banjar". Tradisi Banjar berpegang teguh pada asas gotong royong dan memiliki prinsip bahwa permasalahan yang dihadapi oleh salah satu anggota adalah permasalahan anggota kelompok. Penulis berkeyakinan bahwa pelaksanaan Banjar menjadi upaya pencegahan korupsi. Oleh karena itu, penelitian ini memfokuskan pada pelestarian banjar sebagai pencegahan tindakan korupsi.

\section{Fungsi Banjar}

Juhaepa dan Sarpin (2014) melakukan penelitian yang berfokus pada bentuk dan fungsi banjar serta penyebab perubahan dolidaritas sosial Suku Sasak terkait dengan tergabung atau tidak dalam banjar. Terdapat beberapa hasil temuan dalam penelitian Juhaepa dan Sarpin. Pertama, terdapat dua bentuk banjar yang masih lestari dan dilaksanakan oleh Suku Sasak di Desa Watumelewe, yaitu: banjar merariq (banjar perkawinan) dan banjar mate (banjar kematian). Sedangkan banjar yang sudah tidak lestari karena tidak dilakukan lagi, yaitu: banjar subak. (banjar petani sawah) dan banjar haji (banjar perkumpulan haji). Kedua bentuk banjar yang masih lestari tetap dilaksanakan hingga sekarang karena memiliki fungsi ekonomi dan sosial yang diperlukan oleh masyarakat. Sedangkan kedua banjar yang tidak lagi dilaksanakan oleh masyarakat karena masyarakat memiliki persepsi dan kebutuhan yang berbeda. Hasil temuan yang kedua yaitu solidaritas sosial komunitas Suku Sasak di Desa Watumelewe mengalami perubahan baik positif maupun negatif. Perubahan yang positif terdapat dalam keanggotaan banjar karena tidak lagi mengharuskan dari Suku Sasak tetapi masyarakat di luar Suku Sasak diperbolehkan bergabung. Di lain sisi, perubahan negatif terjadi karena kepedulian sebagian anggota banjar terhadap kelancaran pelaksanaan banjar menurun. Hal tersebut disebabkan oleh faktor internal maupun eksternal. Faktor internal yaitu akibat anggota banjar yang heterogen, sistem yang terbuka, kurang toleransi, dan ketidakpuasan dari anggota. Faktor eksternal yaitu akibat adanya kontak dengan budaya lain.

\section{Pembelajaran Nilai Kearifan Lokal sebagai Penguat Karakter Bangsa}

Wardhani (2013) melakukan sebuah penelitian yang memfokuskan pada bagaimana pembelajaran nilai kearifan lokal melalui pendidikan informal sebagai penguat kearifan lokal. Nilai kearifan lokal yang dikaji terdapat pada tembang Asmarandana dalam Serat Wulung Reh. Hasil temuan menunjukkan bahwa pembelajaran dalam pendidikan informal pada masyarakat Keraton Kasunanan Surakarta tidak memiliki desain atau tidak didesain dalam pembelajaran yang terprogram. Pendidikan informal diselenggarakan secara spontan, sedangkan pembelajaran nilai tersebut ada di dalam pikiran masing-masing. Tembang Asmarandana mengandung tiga nilai, antara lain: nilai Ketuhanan, nilai kemanusiaan, dan nilai kebangsaan. Internalisasi nilai kearifan lokal dilakukan melalui tahapan demi tahapan. Tahapan pertama dimulai dengan mengajarkan bagaimana cara melagukan tembang Asmarandana. Kemudian anak diberitahu makna dari tembang tersebut. Tahapan selanjutnya yaitu pembiasaan melakukan hal-hal yang baik sesuai dengan nilai yang terkandung dalam tembang, salah satunya berbuat 
kebaikan misalnya sholat lima waktu. Pembiasaan tersebut lama kelamaan membentuk anak menjadi berperilaku yang baik. Semua tahapan dalam internalisasi nilai tidak disadari oleh anak bahwa kegiatan tersebut merupakan kegiatan pendidikan informal. Selain perubahan pada aspek afektif dan psikomotor, anak juga memiliki kemampuan kognitif yang ditandai dengan mampu menghafal dan melagukan tembang Asmarandana. Hambatan dalam pelaksanaan pendidikan informal pada pembelajaran nilai kearifan lokal melalui tembang Asmarandana ini, yaitu: kurangnya keteladanan dari orang sekitar, pembelajaran sebagian besar diserahkan sepenuhnya pada sekolah, percampuran nilai budaya asing akibat arus globalisasi dan generasi muda lebih banyak menaruh perhatian pada hal tersebut, fokus pendidikan yang lebih mengutamakan kemampuan akademik dan kurang memperhatikan pada nilai-nilai spiritual, serta kurangnya sinergi antara sekolah, masyarakat, dan keluarga dalam menanamkan dan membelajarkan nilai pada anak didik.

\section{METODE}

Penelitian ini menggunakan pendekatan penelitian kualitatif dengan metode studi kasus. Penulis memilih pendekatan penelitian kualitatif karena berusaha mengetahui penjelasan tentang bagaimana pelestarian tradisi banjar sehingga mendukung pencegahan terjadinya tindakan korupsi di Kampung Kakong, Lombok Utara, Nusa Tenggara Barat. Creswell (2015) mengatakan bahwa pendekatan penelitian kualitatif memiliki ciri-ciri khusus. Ciri yang pertama yaitu peneliti berusaha mengeksplorasi permasalahan dengan tujuan untuk membangun pemahaman terkait fokus kajian secara rinci. Ciri kedua yaitu pendekatan penelitian kualitatif menggunakan tinjauan pustaka untuk menjustifikasi temuan penelitian sehingga tinjauan pustaka tidak berperan sentral dan dapat berkembang sesuai dengan kebutuhan. Ciri ketiga yaitu maksud dan pertanyaan penelitian dirumuskan dan disajikan secara terbuka karena dimaksudkan untuk menangkap pengalaman partisipan. Ciri keempat yaitu data-data yang dikumpulkan untuk keperluan penelitian tidak membutuhkan jumlah partisipan yang banyak karena peneliti membutuhkan pandangan yang mendalam dan spesifik dari sejumlah kecil partisipan. Ciri kelima adalah analisis data menggunakan teknik analisis teks dan penafsiran makna dari temuan penelitian. Ciri keenam yaitu penulisan laporan penelitian dilakukan secara fleksibel dan bersifat evaluatif dengan memasukkan refleksi dan bias subjektif peneliti.

Peneliti menggunakan metode penelitian studi kasus karena peneliti berusaha mendeskripsikan fenomena unik dalam pelaksanaan banjar pada masyarakat suku Sasak Kampung Kakong, Lombok Utara, Nusa Tenggara Barat. Ary, dkk. (2012) mengemukakan bahwa metode studi kasus digunakan dalam penelitian karena penelitian hanya berfokus pada fenomena khusus dan peneliti yakin sesuatu dapat dipelajari dari fenomena khusus tersebut. Metode studi kasus juga digunakan untuk menjawab pertanyaan deskriptif tentang apa yang terjadi atau menjelaskan suatu kejadian dengan melihat pada proses.

Hennink, dkk. (2011) mengemukakan bahwa peneliti yang menggunakan pendekatan penelitian kualitatif berusaha untuk memperoleh pengalaman seseorang secara mendetail dan dapat menggunakan beberapa teknik pengumpulan data yang khusus, yaitu: wawancara mendalam, focus group discussion (FGD), observasi, analisis konten, visual methods, dan sejarah kehidupan atau biografi. Penelitian ini menggunakan dua teknik pengumpulan data, yaitu: wawancara dan studi literature. Menurut Sugiyono (2011), dalam penelitian kualitatif, peneliti berperan sebagai buman instrument yang menetapkan fokus penelitian, memilih informan, menafsirkan data dan menarik kesimpulan dari temuan penelitian. Partisipan penelitian dipilih dengan menggunakan teknik purposive sampling. (Creswell, 2015). Partisipan terdiri atas orang-orang suku Sasak yang aktif melaksanakan tradisi banjar di Kampung Kakong, Lombok Utara, Nusa Tenggara Barat.

\section{HASIL DAN PEMBAHASAN}

\section{Korupsi}

Undang-Undang Nomor 31 Tahun 1999 (sebagaimana telah diubah dengan UndangUndang Nomor 20 Tahun 2001) Tentang Pemberantasan Tindak Pidana Korupsi selanjutnya disebut UU TPK Korupsi mengatur tentang tindakan korupsi termasuk definisinya. Menurut Pasal 2 Ayat (1), korupsi memiliki definisi sebagai berikut: 
Novitasari dan Ahmad Busrotun Nufus: Pelestarian Banjar sebagai...

"Setiap orang yang secara melawan hukum melakukan perbuatan memperkaya diri sendiri atau orang lain atau suatu korporasi yang dapat merugikan keuangan negara atau perekonomian negara, dipidana penjara dengan penjara seumur hidup atau pidana penjara paling singkat 4 (empat) tahun dan paling lama 20 (dua puluh) tahun dan denda paling sedikit Rp. 200.000.000,00 (dua ratus juta rupiah) dan paling banyak Rp. 1.000.000.000,00 (satu milyar rupiah)."

Definisi tersebut berarti bahwa korupsi merupakan sebuah tindakan yang dilakukan dapat merugikan negara dalam hal keuangan atau perekonomian. Nye (dalam Salama, 2010) mendefinisikan korupsi sebagai perilaku yang menyimpang dari tugas formal sebagai pegawai publik untuk mendapatkan keuntungan finansial atau meningkatkan status. Selain itu, juga bisa diperoleh keuntungan secara material, emosional, atau pun simbol. Kejahatan korupsi tersebut dilakukan secara sadar dan penuh perhitungan matang. Jadi bisa diambil kesimpulan bahwa korupsi merupakan tindakan menyimpang yang dilakukan secara sadar oleh seseorang untuk mendapatkan keuntungan baik secara material ataupun emosional dan Kejahatan korupsi lebih cenderung dilakukan oleh seorang pegawai yang mengemban jabatan tertentu. Dengan demikian, definisi korupsi dapat bergantung pada konteks yang sedang dikaji, namun pada umumnya korupsi didefinisikan suatu perilaku yang tidak sesuai dengan nilai-nilai yang hidup dalam kehidupan bermasyarakat dan bernegara.

Utari mengatakan bahwa individu yang korup akan terbentuk dalam masyarakat yang memiliki sistem budaya dan lembaga yang korup meskipun individu tersebut memiliki kesalehan yang besar (2011; Fauziyah, 2015). Samad (2013) mengemukakan bahwa faktor penyebab korupsi ada lima, antara lain: (1) sikap permisif terhadap korupsi; (2) peraturan perundangan belum memadai; (3) lemahnya law enforcement; (4) lemahnya sistem penyelenggaraan negara, pengelolaan dunia usaha, dan masyarakat tidak mengindahkan prinsip-prinsip good gevernance; (5) lemahnya integritas moral, pendapatan/penghasilan yang rendah, dan lain sebagainya.

\section{Pendidikan Karakter dan Budaya Anti- Korupsi}

Rakhmat (2012; Wardhani, 2016) mengemukakan bahwa terdapat tiga aspek yang menjadi sasaran pendidikan karakter, yaitu: aspek kognitif, afektif, dan psikomotor. Aspek kognitif yang dimaksudkan adalah pendidikan karakter dilaksanakan untuk mengisi otak yang dari awalnya tidak tahu menjadi tahu hingga dapat memiliki kecerdasan intelegensia. Aspek afektif yaitu yang berkaitan dengan perasaan dan emosi sehingga memiliki kecerdasarn emosional. Aspek psikomotorik yaitu yang berkaitan dengan tindakan dan keterampilan. Budaya anti-korupsi memiliki kaitan erat dengan pendidikan karakter karena menanambkan karakter anti-korupsi sehingga menjadi budaya dalam kehidupan seharihari. Zubaedi mengatakan bahwa pengembangan karakter adalah proses yang terjadi secara terus menerus (2011). Helen G. Douglas (dalam Samani \& Hariyanto, 2016), menjelaskan bahwa "character isn't inherented. One builds its daily by the way one thinks and acts, thought by thougt, action by action". Karakter seseorang dapat dibangun dari hari ke hari secara berkesinambungan melalui pikiran dan perbuatan karena karakter merupakan sesuatu yang diwarisi atau diwariskan. Budaya anti-korupsi berkaitan erat dengan pendidikan karakter karena untuk membudayakan nilai-nilai anti korupsi sama dengan membentuk karakter seseorang untuk memiliki nilai-nilai anti-korupsi. Terdapat 9 (sembilan) nilai anti korupsi yang berusaha ditanamkan pada masyarakat, antara lain: jujur, disiplin, tanggung jawab, kerja keras, sederhana, mandiri, adil, berani, dan peduli.

\section{Pelestarian Tradisi Banjar di Kampung Kakong}

Masyarakat suku Sasak memliki berbagai budaya yang masih dilaksanakan yang salah satunya disebut tradisi banjar. Banjar merupakan suatu bentuk solidaritas masyarakat suku Sasak yang diikat oleh suatu kesepakatan dan berwujud bantuan dalam hal tenaga, uang, dan pemikiran. Masing-masing kampung di Lombok memiliki tata cara tersendiri dalam melaksanakan tradisi banjar, salah satunya di Kampung Kakong, Kabupaten Lombok Utara, Provinsi Nusa Tenggara Barat. 
Tradisi banjar di kampong Kakong dapat diikuti oleh seluruh masyarakat secara sukarela tanpa ada paksaan karena didasarkan pada asas gotong royong dan kebutuhan pribadi. Meskipun demikian, keanggotaan masyarakat yang ikut melaksanakan tradisi banjar tetap didata karena terkait dengan iuran dan koordinasi dalam pelaksanaan setiap begawe. Begawe adalah suatu bentuk kegiatan yang melibatkan banyak orang dalam rangka merayakan sesuatu, misalnya khitanan, pernikahan, berangkat haji, hingga mendoakan sanak keluarga yang sudah meninggal. Anggota banjar merupakan orang-orang yang sudah menikah dan berkeluarga. Orang-orang yang bukan suku Sasak dan tinggal di Kampung Kakong juga diperbolehkan untuk gabung ke dalam keanggotaan banjar. Koordinasi antar anggota banjar dikoordinir oleh penguruh harian perkumpulan banjar. Selain rapat yang digelar dalam rangka akan diadakan suatu acara, terdapat iuran yang ditarik dari para anggota banjar dan untuk kepentingan para anggota banjar sendiri. Keberadaan anggota banjar sangat penting pada saat akan diadakan begawe. Tradisi banjar yang dilaksanakan pada saat perayaan pernikahan disebut sebagai banjar merariq. Begawe pada banjar merariq dilaksanakan mulai beberapa hari sebelum acara akad nikah hingga menerima kedua mempelai setelah nyongkolan. Nyongkolan adalah kegiatan mengarak kedua mempelai dari rumah mempelai laki-laki menuju rumah mempelai perempuan.

Terdapat dua perkumpulan banjar yaitu banjar bapak-bapak dan banjar ibu-ibu. Banjar bapakbapak pada saat begawe biasanya bertugas untuk mendirikan tenda, mencari kayu, dan kegiatan membutuhkan tenaga besar. Sedangkan banjar ibu-ibu bertugas untuk memasak, membuat kue, dan kegiatan lainnya yang mendukung kelancaran begawe. Anggota banjar yang tidak datang bahkan jarang dating maka hal sama akan dilakukan oleh anggota lain terhadapnya. Oleh karena itu, keanggotaan banjar yang sifatnya sukarela terikat dengan dua prinsip yaitu berdasarkan solidaritas karena sesasama manusia harus saling tolong menolong dan berdasarkan pada alasan pribadi karena apabila ikut membantu pelaksanaan begawe seorang anggota banjar maka akan dibantu juga pada saat orang tersebut ada begawe.

Persiapan sebelum begawe hingga penerimaan kedua mempelai setelah proses arak-arakan diselenggarakan dalam waktu kurang lebih lima hari hingga satu minggu. Begawe akan membutuhkan biaya yang besar karena membutuhkan konsumsi yang banyak. Pada saat begawe, setiap anggota banjar biasanya membawa keluarga untuk ikut serta meskipun yang menjadi anggota banjar adalah orang tuanya. Mulai dari anak kecil hingga orang dewasa akan berkumpul dalam pelaksanaan begawe tersebut. Tuan rumah tidak hanya menyediakan makan untuk tamu tetapi juga untuk para anggota banjar beserta dengan keluarganya yang ikut datang. Bahkan sebagian orang tua tidak memasak makanan di rumah masing-masing pada saat salah satu anggota banjar ada begawe karena pasti akan ada banyak makanan dalam begawe tersebut. Selain itu, para anggota banjar juga semakin sibuk pada saat membantu pelaksanaan begawe salah satu anggota banjar sehingga tidak sempat untuk masak. Pada saat begawe, sejak pagi para anggota banjar akan membantu segala kegiatan di rumah anggota banjar yang melaksanakan begawe. Oleh karena itu, biaya dalam pelaksanaan begawe khususnya pada konsumsi membutuhkan biaya yang besar. Begawe akan selesai ketika kedua mempelai diterima setelah diarak dari rumah mempelai laki-laki.

Para orang tua yang menjadi anggota banjar akan mengajak anak-anaknya untuk ikut serta membantu dalam begawe di rumah salah satu anggota banjar yang lain. Anak-anak yang masih kecil akan melihat kekompakan para anggota banjar dalam membantu begawe tersebut. Bahkan tidak jarang ada anak kecil yang ikut serta membantu mengerjakan sesuatu misalnya membungkus jajan meskipun hasilnya kurang bagus. Remaja hingga dewasa yang belum menikah akan dibiasakan untuk tanggap terhadap kegiatan yang sekiranya harus dilakukan dalam begawe, misalnya mengantar makanan dan minuman kepada para tamu. Tuan rumah yang punya acara sangat terbantu oleh semua anggota banjar yang hadir dan membantu selama prosesi begawe. Meskipun demikian, terdapat beberapa anggota banjar yang sudah menjadi langganan untuk mengatur keperluan-keperluan tertentu selama pelaksanaan begawe. Keperluan-keperluan yang diatur biasanya adalah keperluan hidangan, sayur, daging, dan nasi. Orang-orang yang mengatur keperluan-keperluan tersebut disebut sebagai Ran, misalnya ran sayur yaitu orang yang mengatur tentang keperluan sayur selama acara begawe. 
Novitasari dan Ahmad Busrotun Nufus: Pelestarian Banjar sebagai...

Pemilihan ran-ran tersebut berdasarkan pada pengalaman yang dimiliki. Sedangkan apabila orang tersebut berhalangan hadir maka pemilihan ran akan dilakukan melalui musyawarah.

\section{Pencegahan Korupsi melalui Pelestarian Tradisi Banjar}

Pelestarian tradisi banjar di lingkungan keluarga dan masyarakat dilaksanakan dengan menggunakan pendidikan karakter karena pembudayaan nilai-nilai anti-korupsi erat kaitannya dengan pembentukan karakter seseorang. Pendidikan karakter di masyarakat suku Sasak di Kampung Kakong dilaksanakan tanpa terstruktur dan tertulis seperti yang ada dalam pelestarian tradisi banjar. Tradisi banjar mengandung Sembilan nilai-nilai anti-korupsi sehingga melestarikan tradisi banjar sama dengan melaksanakan pendidikan karakter di lingkungan keluarga dan masyarakat.

Winataputra (2012) mengatakan bahwa pelaksanaan pendidikan karakter di lingkungan keluarga dan masyarakat diupayakan melalui proses penguatan dari orang tua dan tokoh-tokoh masyarakat sehingga dapat dijadikan panutan terhadap perilaku berkarakter mulia bagi peserta didik. Perilaku-perilaku yang mulai tersebut dikembangkan sehingga menjadi kegiatan keseharian di rumah dan di lingkungan masyarakat. Kesembilan nilai tersebut yaitu, nilai kejujuran, kedisiplinan, tanggung jawab, kerja keras, kesederhanaan, kemandirian, keadilan, keberanian, dan kepedulian. Nilai kejujuran dalam tradisi banjar dapat dilihat pada saat anggota banjar dipercaya tuan rumah yang punya begawe untuk mengatur segala keperluan selama prosesi begawe. Uslaner (Angraeni, 2016) mengatakan bahwa ada keterkaitan antara korupsi dan budaya. Budaya yang didominasi dengan nuansa "mis-trust" memiliki kaitan yang erat dengan tingkat korupsi yang tinggi. Sedangkan, budaya yang didominasi dengan nuansa "trust" berkorelasi positif dengan tingkat korupsi yang rendah. Nilai kedisiplinan terlihat pada saat persiapan dan pelaksanaan begawe. Menurut Kemendiknas (2010; Wibowo, 2012), disiplin adalah tindakan yang menunjukkan perilaku tertib dan patuh pada berbagai ketentuan dan peraturan. Sanksi sosial akan dikenakan pada anggota banjar yang tidak disiplin dalam membantu pelaksanaan begawe meskipun aturan tersebut tidak tertulis. Nilai tanggung jawab tersirat pada perilaku para anggota banjar yang diberikan amanah untuk membantu mengatur segala keperluan selama begawe. Kerja keras terlihat jelas selama persiapan dan prosesi begawe diselenggarakan. Kerja keras tersirat dalam perilaku setiap orang yang dating karena hampir semua orang anggota banjar di Kampung Kakong datang untuk membantu tuan rumah yang punya begawe. Nilai kesederhanaan dapat dilihat dari pelaksanaan begawe. Meskipun tenaga dan pemikiran serta sebagian dana dibantu oleh anggota banjar yang datang, pelaksanaan begawe menyesuaikan dengan kemampuan finansial tuan rumah. Nilai kemandirian dapat dilihat dari sumber dana yang digunakan tuan rumah untuk menyelenggarakan begawe. Nilai keadilan dapat dilihat dari bentuk apresiasi yang diberikan oleh tuan rumah yang punya begawe kepada para anggota banjar yang datang membantu. Apresiasi diberikan sesuai dengan tugas dan tanggung jawab yang diemban. Nilai keberanian terlihat pada perilaku masing-masing anggota banjar baik yang datang membantu maupun tuan rumah yang punya begawe. Keberanian anggota banjar yang datang membantu terlihat pada saat menerima amanah untuk menjalankan sebuah tugas. Misalnya, seorang anggota banjar berani mengemban amanah sebagai ran beras sehingga berani mengambil resiko untuk bertanggung jawab apabila terdapat kesalahan pada saat menjalankan amanah.

Implementasi pendidikan karakter di lingkungan keluarga dan masayrakat Kampung Kakong selama melestarikan tradisi banjar dilaksanakan melalui proses pembudayaan dan pemberdayaan. Menurut Winataputra (2012), pendidikan karakter diselenggarakan oleh tri pusat pendidikan, antara lain: satuan pendidikan, keluarga, dan masyarakat. Pada masing-masing pilar pendidikan diusahakan untuk membangun pengalaman belajar melalui dua pendekatan, yaitu: intervensi dan habituasi. Pendekatan intervensi dikembangkan suasana interaksi belajar dan pembelajaran untuk mencapai pembentukan karakter dengan menerapkan kegiatan yang terstruktur. Sedangkan pada pendekatan habituasi dilciptakan situasi dan kondisi (persistent-life situation), dan penguatan (reinforcement) yang memungkinkan peserta didik membiasakan diri berperilaku sesuai nilai. Kebiasaan tersebut diharapkan dapat menjadi karakter karena telah diinternalisasi melalui proses intervensi. Dengan 
demikian, proses pembudayaan dan pemberdayaan dalam melestarikan tradisi banjar dilakukan melalui pemberian contoh dan pembiasaan. Akan tetapi, penyelenggaraan pengembangan karakter oleh tri pusat pendidikan tersebut tidak dapat dilepaskan dari dukungan dan komitmen seluruh sektor kehidupan terutama membutuhkan keterlibatan aktif dari sektor-sektor pemerintahan.

Angraeni (2016) mengemukakan bahwa pendidikan antokorupsi dapat dipahami sebagai upaya pengembangan segala potensi yang dimiliki masyarakat untuk mewujudkan budaya antikorupsi dalam kehidupan masyarakat, berbangsa, dan bernegara. Potensi yang dimaksud yaitu nilai dan norma yang menjadi pedoman kehidupan seharihari. Budaya anti korupsi yang terbangun akan mendorong masyarakat untuk memiliki karakter yang baik. Karakter yang baik atau good character meliputi tiga proses psikologis yaitu mengetahui hal yang baik (knowing the good), menginginkan hal yang baik (desiring the good), dan melakukan hal yang baik (doing the good) (Lickona, 2015; Wibowo, 2012). Substansi dari ketiga proses psikologis tersebut bermuara pada kehidupan moral dan kematangan moral individu (Winataputra, 2012, hlm. 46). Dengan demikian, orang yang berkarakter adalah orang yang memiliki integritas sehingga pikiran, perasaan, dan kehendak serta perilakunya sejalan dan konsisten.

\section{PENUTUP}

\section{Simpulan}

Salah satu kearifan lokal di Lombok yaitu banjar mengandung nilai-nilai anti korupsi. Nilai-nilai anti korupsi tersebut, antara lain jujur, disiplin, tanggung jawab, kerja keras, sederhana, mandiri, adil, berani, dan peduli. Nilai-nilai tersebut terlihat pada perilaku para anggota banjar saat mempersiapkan dan melaksanakan begawe khususnya begawe merariq. Pelaksanaan banjar telah mendarah daging bagi masyarakat Lombok khususnya Lombok Utara. Pengenalan tentang banjar kepada para generasi penerus dilakukan baik melalui pembiasaan di masyarakat maupun melalui sebuah wejangan oleh orang tua kepada anak. Dengan demikian, banjar dapat menjadi upaya masyarakat khusus di Lombok untuk membangun budaya anti korupsi.

\section{Saran}

Berdasarkan hasil temuan dan penelitian, maka penulis memberikan saran terkait penelitian yaitu sebagai berikut: 1) Pencegahan korupsi melalui pelestarian banjar penting dilakukan dengan melibatkan keluarga, masyarakat, dan sekolah; dan 2) Kurikulum pendidikan di sekolah dasar hingga pendidikan tinggi dapat disisipkan materi tentang nilai-nilai anti korupsi dalam tradisi banjar sehingga dapat dilakukan penilaian secara terstuktur.

\section{Ucapan Terima Kasih}

Penulis mengucapkan terima kasih kepada semua pihak yang telah berjasa dalam membantu menyelesaikan penulisan hasil penelitian ini termasuk partisipan penelitian. Terima kasih juga kami sampaikan kepada Fakultas Ilmu Sosial dan Poiltik Universitas Tidar karena telah memberikan motivasi dan dukungan kepada penulis untuk selalu berkarya dan produktif.

\section{DAFTAR PUSTAKA}

Angraeni, Sari. (2016). Program Pencegahan Korupsi Berbasis Keluarga. Jakarta: KPK.

Ary, Donald, dkk. (2010). Introduction to Research in Education 8th Edition. USA: Wadsworth.

Budiawati, Arie Dwi. (2018). Daftar Terbaru Negara Terkorup, Indonesia Rangking Berapa?.

https://www.dream.co.id/unik/daftar-

terbaru-negara-terkorup-indonesia-rankingberapa-180223d.html

Creswell, John. (2015). Riset Pendidika: Perencanaan, Pelaksanaan, dan Evaluasi Riset Kualitatif \& Kuantitatif. Yogyakarta: Pustaka Pelajar.

Fauziyah, Fitri. (2015). Nilai-Nilai Pendidikan Antikorupsi dalam Alqur'an: Kejujuran, Tanggung Jawab dan Kesederhanaan. http://eprints.ums.ac.id/39791/1/NASKA H\%20PUBLIKASI.pdf

Hennink, Monique, et al. (2011). Qualitative Research Methods. London: Sage Publication Ltd. 
Novitasari dan Ahmad Busrotun Nufus: Pelestarian Banjar sebagai...

Juhaepa dan Sarpin. 2014. Fungsi Banjar dalam Budaya Suku Sasak terhadap Solidaritas Sosial Masyarakat di Desa Watumelewe Kecamatan Tinanggea Kabupaten Konawe Selatan. Societal: Jurnal Pemikiran dan Penelitian Sosiologi, Vol. 1 (1) hlmn. 89-99.

Kemendiknas. (2010). Pengembangan Pendidikan Budaya dan Karakter Bangsa Pedoman Sekolah.

http://gurupembaharu.com/home/wpcontent/uploads/downloads/2011/11/Pan duan-Penerapan-Pendidikan-KarakterBangsa.pdf

Kurniawan, Hendra. (2014). Dampak Sistem Tanam Paksa terhadap Dinamika Perekonomian Petani Jawa 1830-1870. Socia vol. 11(2), hlmn. 163-172.

Lickona, Thomas. (2015). Character Matters Persoalan Karakter Bagaimana Membantu Anak Mengembangkan Penilaian yang Baik, Integritas, dan Kebajikan Penting Lainnya. Diterjemahkan oleh Juma Abdu Wamaungo \& Jean Antunes Rudolf Zien. Jakarta: Bumi Aksara.

Muskanan, Frans Wilmat. (2014). Kinerja Direktorat Penyelidikan, Penyidikan, dan Penuntutan Komisi Pemberantasan Korupsi dalam Menindaklanjuti Laporan Tindak Pidana Korupsi Periode 2012-2013. Politika, Vol. 5 (1). https://ejournal.undip.ac.id/index.php/poli tika/article/viewFile/8213/6734

Rahmatulloh, Johan. (2017). Legalitas Kewenangan Penyelenggara Pendidikan dalam Menarik Pungutan di Satuan Pendidikan Dasar. Integritas, vol. 3(2). Hlm. 137-156. https://jurnal.kpk.go.id/index.php/integrit as/issue/view/7/Jurnal-INTEGRITASVolume-3-No-2-tahun-2017

Salama, Nadiatus. (2010). Fenomena Korupsi Indonesia (Kajian Mengenai Motif dan Proses Terjadinya Korupsi). Semarang: Pusat Penelitian IAIN Walisongo Semarang.

Samad, Abraham. (2013). Pemberantasan Korupsi: Pilihan Tepat untuk Mensejahterakan Rakyat dan Menegakkan Pilar Kebangsaan. https://akademik.ugm.ac.id/2017/wp- content/uploads/2016/12/2013_makalah_ kuliah_perdana_pascasarjana_ugm.pdf

Samani, Muchlas, \& Hariyanto. (2016). Konsep dan Model: Pendidikan Karakter. Bandung: PT. Remaja Rosdakarya.

Undang-Undang Republik Indonesia Nomor 20 Tahun 2001 Tentang Pemberantasan Tindak Pidana Korupsi

Undang-Undang Republik Indonesia Nomor 31 Tahun 1999 Tentang Pemberantasan Tindak Pidana Korupsi.

Utari, Indah Sri. (2011). Faktor Penyebab Korupsi. http:/ /elista.akprind.ac.id/fti/Pendidi kan \%20Anti\%20Korupsi/MasterBukuPendidikan-Anti-Korupsiuntuk-PerguruanTinggi2012_1.pdf

Wardhani, Novia Wahyu. (2013). Pembelajaran Nilai-Nilai Kearifan Lokal sebagai Penguat Karakter Bangsa melalui Pendidikan Informal. Jurnal Penelitian Pendidikan, Vol. 13 http://ejournal.upi.edu/index.php/JER/art icle/view/3504/2487

Wibowo, Agus. (2012). Pendidikan Karakter Strategi Membangun Karakter Berperadaban. Yogyakarta: Pustaka Pelajar.

Winataputra, Udin Saripudin. (2012). Pendidikan Kewarganegaraan dalam Perspektif Pendidikan untuk Mencerdaskan Kehidupan Bangsa (Gagasan, Instrumentasi, dan Praksis). Bandung: Widya Aksara Press.

Zubaedi. (2011). Desain Pendidikan Karakter: Konsepsi dan Aplikasinya dalam Lembaga Pendidikan. Jakarta: Prenadamedia Group. 